\title{
Seroprevalence of Hepatitis B Surface Antigen Positive Patients Attending a Tertiary Care Hospital in Srikakulam, Andhra Pradesh
}

\author{
Aruna Bula ${ }^{1 *}$, Santhosh Ram Gaddam² \\ 'Department of Microbiology, Rajiv Gandhi Institute of Medical Sciences (RIMS), Srikakulam, Andhra Pradesh, India \\ ${ }^{2}$ Department of Orthopaedics, Andhra Medical College, Visakhapatnam, Andhra Pradesh, India
}

\begin{abstract}
Background: Hepatitis B virus (HBV) infection continues to be a serious public health problem globally and studying the prevalence of HBV infection in a geographical area aids in establishing magnitude of the problem. A teaching hospital based population study of Hepatitis B surface antigen ( $\mathrm{HBsAg}$ ) is a strong indicator of true $\mathrm{HBV}$ infection rate in the community as large number of patients from different backgrounds attend the hospital.

Methods: A one step rapid immunochromatographic method for detection of HBsAg was performed to diagnose HBV infection. 24,028 sera samples were tested over a period of one year 9 months.

Result: Out of the 24,028 samples tested for HBsAg, 733 (3.05\%) were found to be positive for HBsAg. Positivity rate was more among males $440(60.02 \%)$ than females $293(39.97 \%)$ and the most common age group in males was 41-50 years (23.18\%) followed by $31-40$ years $(22 \%)$.In females, commonest age group was $21-30$ years $(38.22 \%)$ followed by $31-40$ years $(14.67 \%)$.

Conclusion: The study helps to know the magnitude of viral transmission in the community \& to know the at risk age groups. Seroprevalence of HBsAg in Srikakulam, Andhra Pradesh was found to be 3.05\% which is in accordance with the national average of $2-7$ $\%$ and it falls into intermediate zone of HBsAg prevalence according to WHO.
\end{abstract}

Keywords: Hepatitis B, HBsAg, Prevalence, Srikakulam

\section{Introduction}

Hepatitis B virus (HBV) infection, a global health problem that causes a spectrum of disease ranging from self limiting hepatitis to acute fulminant and chronic hepatitis leading to sequelae like liver cirrhosis and hepatocellular carcinoma remains the 10th leading cause of death and $5^{\text {th }}$ most frequent cancer worldwide. ${ }^{[1,2]}$ It causes $60-80 \%$ of all primary liver cancers, and $30 \%$ of the world's population show serological evidence of current or past infection with HBV. ${ }^{[3]}$

To understand and assess the magnitude and dynamics of transmission of a disease in a community and for its control and prevention, the assessment and study of its prevalence is very important. This study was undertaken to estimate the burden of $\mathrm{HBV}$ infection in this part of country, and to compare with the prevalence rates in different parts of India.

\section{Materials And Methods}

The study was conducted at Rajiv Gandhi Institute of Medical Sciences (RIMS), Srikakulam, Andhra Pradesh from January 2015 to September 2016.After obtaining permission from Institutes ethics committee, patients who registered at the OPDs or were admitted to the IPDs of the hospital were included in the study. Blood sample to obtain serum was collected with standard precautions.

A $5 \mathrm{ml}$ venous blood sample was collected from all patients. The blood was allowed to clot for 45 mins at room temperature and the serum was separated after centrifugation. The serum sample was then subjected to the test. A one step rapid immunochromatographic assay(ICA) Aspen(Aspen Laboratories Pvt. Ltd ,Delhi) kit with sensitivity of $>99.9 \%$ and specificity of $99 \%$ for qualitative detection of HBsAg was employed.

\section{Results}

Sera of 24,028 patients were tested for HBsAg over a period of one year nine months from January 2015 to September 2016. 733 Patients (3.05\%) were tested positive for HBsAg. Positive prevalence was higher among males 440(60.02 $\%$ ) compared to that of females 293(39.97\%). Analysis of age distribution of HBsAg positive cases in both genders revealed a higher prevalence of HBsAg among men of 
age 41-50 years $102(23.18 \%)$ followed by 31-40 years 97 $(22.04 \%)$. (Table 1) In females, highest prevalence was seen among 21 -30 years age group 112(38.22\%) followed by $31-40$ years age group $43(14.67 \%)$. (Table 1 )

Table 1: Age wise Distribution of HBsAg positive male patients $(n=440) \&$ female patients $(n=293)$.

\begin{tabular}{|c|c|c|c|c|}
\hline \multirow{2}{*}{ Age } & \multicolumn{2}{|c|}{ male patients $(\mathbf{n = 4 4 0 )}$} & \multicolumn{2}{c|}{ female patients $(\mathbf{n = 2 9 3 )}$} \\
\cline { 2 - 5 } & No.of HBsAg positive sera & Percentage (\%) & No.of HBsAg positive sera & Percentage (\%) \\
\hline $0-10$ & 6 & 1.36 & 2 & 0.68 \\
\hline $11-20$ & 19 & 4.31 & 112 & 12.96 \\
\hline $21-30$ & 68 & 15.45 & 43 & 38.22 \\
\hline $31-40$ & 97 & 22.04 & 39 & 14.67 \\
\hline $41-50$ & 102 & 23.18 & 41 & 13.31 \\
\hline $51-60$ & 83 & 18.86 & 16 & 13.99 \\
\hline $61-70$ & 54 & 12.27 & 2 & 5.46 \\
\hline$>71 \&$ above & 11 & 2.5 & & 0.68 \\
\hline
\end{tabular}

Table 2: Comparison of Prevalence of HBV with various studies in India.

\begin{tabular}{|l|c|c|c|c|c|}
\hline Author & Place of study & Year of study & $\begin{array}{c}\text { No.of samples } \\
\text { tested }\end{array}$ & Study Population & Prevalence (\%) \\
\hline Smitha Sood et al & Jaipur,Rajasthan & $2007-2008$ & 3196 & General population & 0.87 \\
\hline Sayed A.Quadri et al & Bijapur,Karnataka & 2010 & 4283 & General population & 1.63 \\
\hline Smitha Sood & Jaipur,Rajasthan & $2010-2011$ & 9515 & General population & 1.73 \\
\hline Irfa Naqshbandi et al & Srinagar,Kashmir & $2011-2013$ & 1300 & General population & 1.2 \\
\hline Piyush et al & Ahmedabad & $2005-2011$ & 5316 & Blood donors & 0.3 \\
\hline Supekhar Shilpa et al & Gujarat & 2012 & 1152 & Students & 0.694 \\
\hline K.S.Saraswathi et al & Hyderabad,Telangana & $2010-2012$ & 2155 & Pregnant & 0.9 \\
\hline M.Khaleel et al & Hyderabad,Telangana & 2015 & 2500 & Blood donors & 1.2 \\
\hline Samatha et al & Andhra Pradesh & $2013-2014$ & 2851 & General Population & 2.42 \\
\hline Singh J et al & Andhra Pradesh & 2000 & 737 & General Population & 3.3 \\
\hline Yedlapati Bhavani et al & Andhra Pradesh & $2004-2009$ & 8097 & Blood donors & 1.41 \\
\hline Chandra M etal & Andhra Pradesh & 2015 & 800 & Tribal population & 5.16 \\
\hline Ashish Batham et al & India & 2009 & $8,84,052$ & All & 3.07 \\
\hline Present study & Srikakulam, & $2015-2016$ & 24,028 & General population & 3.05 \\
\hline
\end{tabular}

\section{Discussion}

Hepatitis B is the most common chronic viral infection in humans. Inspite of a vaccine available since 1982, the hepatitis B virus (HBV) remains a serious global public health problem.

Prevalence of HBV infection varies greatly in different parts of the world. HBV prevalence has been classified by the World Health Organisation (WHO) into high endemicity (> $8 \%)$, Intermediate $(2-7 \%)$ and low endemicity areas $(<2 \%)$. ${ }^{[1]}$ India with 40 million HBsAg carriers and about 1,00,000 deaths every year due to illness related to HBV infection, has been placed into the intermediate zone of prevalence rates by $\mathrm{WHO}^{[4]}$ Human hepatitis B virus (HBV), a small enveloped virus belonging to Hepadnaviridae family, has a partially double stranded circular deoxyribonucleic acid (DNA) that replicate by reverse transcription. ${ }^{[5]}$

The genome has four overlapping genes:S gene, $\mathrm{C}$ gene, $\mathrm{P}$ gene and $\mathrm{X}$ gene $\& 8$ genotypes, $\mathrm{A}$ to $\mathrm{H}$ classified based on genetic sequence variability between genotypes of more than $8 \%$.

- S gene codes for the surface antigen ( $\mathrm{HbsAg})$,

- C gene codes for core $\mathrm{Ag}(\mathrm{HBcAg})$ and $\mathrm{HBeAg}$,

- P gene codes for DNA polymerase enzyme and

- X gene codes for a small non particulate protein $(\mathrm{HBXAg}) .{ }^{[6]}$ 
Patients with mutations in the precore or core region fail to secrete $\mathrm{HBeAg}$ but continue to replicate actively causing progressive liver disease. Upto $20 \%$ of patients who develop HBeAg seroconversion may reactivate becoming HBeAg positive again. Thus regular followup with quantitative measurement of hepatitis B virus DNA and aminotransferase levels is required after seroconversion to ensure its durability. ${ }^{[7]}$

The primary routes of transmission are perinatal,early childhood exposure,sexual contact,and per cutaneous exposure to blood or body fluids (i.e injections, needle stick, blood transfusion). ${ }^{[2]}$ Other routes of transmission include nosocomial infections, organ transplantation, tattooing and high risk occupations. A large proportion of patients suffering from Hepatitis B may be aymptomatic and can transmit the disease to healthy population. ${ }^{[2]}$ Serologic markers of $\mathrm{HBV}$ infection diagnosis vary depending on whether the infection is acute or chronic. HBsAg is the most commonly used test for diagnosing acute HBV infections or detecting carriers. ${ }^{[3]}$

In our study conducted on 24,028 samples of hospital based population comprising of rural and urban population of all age groups and both sexes, over a period of one year nine months from January 2015-September 2016 in Rajiv Gandhi Institute of Medical Sciences (RIMS), Srikakulam, Andhra Pradesh, the prevalence of $\mathrm{HBsAg}$ was found to be $3.05 \%$.

The study shows that the positive prevalence was significantly higher in males 440 (60.02\%) compared to that of females 293 (39.97\%). Higher infection in men may be due to their frequent exposure to risk factors such as injecting drug use, having multiple sexual partners or other risk behaviours.

In males, the common age group was found to be 3150 years wheareas in females it was 21- 40 years.HBV infection being higher in these age groups may be due to their greater exposure \& interaction in society as compared to children or elders.

In different studies conducted in a hospital based population of Katuri Medical college, Andhra Pradesh by Samatha et al ${ }^{[12]}$ and in local population of Rajamundry, Andhra Pradesh by Singh $\mathrm{J}$ et $\mathrm{al}^{[13]}$, the prevalence rate of Hepatitis B surface antigen was found to be $2.42 \%$ and $3.3 \%$ respectively. Seroprevalence in tribal areas of Andhra Pradesh was found to be higher when compared to non tribal areas. ${ }^{[15]}$ Also in a recent study on the systemic review and meta analysis of the prevalence of hepatitis B in India by Ashish Batham et al, the state of Andhra Pradesh, showed a prevalence of $3.256 \%$ in nontribal areas and
$5.004 \%$ in tribal areas. ${ }^{[16]}$ (Table 5) Seroprevalence of Hepatitis B surface antigen (HBV) in the present study $(3.05 \%)$ closely coincides with the prevalence of above studies done in Andhra Pradesh.

Various other studies done in different places of the country in the past 10 years in different study population showed prevalence ranging from $0.3 \%$ to $1.73 \%$ in non tribal areas. (Table 2) According to WHO classification, Srikakulam District, Andhra Pradesh falls into Intermediate zone of prevalence as prevalence was between $2-7 \%$.

\section{Conclusion}

India has approximately $\mathrm{HBV}$ carrier rate of $3.0 \%$ with a high prevalence rate in the tribal population. It is important to carry out larger studies to better elucidate the epidemiology of HBV and identify high prevalence areas. The present study helps to know the magnitude of viral transmission in the community \& to know the at risk age groups. Seroprevalence of HBsAg in Srikakulam, Andhra Pradesh was found to be in accordance with the national average of $2-7 \%$.

Most of the India's carrier pool is established by horizontal spread due to crowded living conditions \& poor hygiene. Keeping in view, the increasing burden of this disease, there is a need to organize health education campaigns targeting both health care workers as well as public, so that they adopt all possible measures including immunisation to prevent disease transmission and decrease the burden of the disease.

\section{References}

1. Quadri SA, Dadapeer HJ, Arifulla KM, Khan N. Prevalence of Hepatitis B Surface Antigen in hospital based population in Bijapur,Karnataka. Al Ameen J Med Sci 2013;6(2):180-182.

2. Sood S. Serological Evaluation of Hepatitis B Virus in out patient Department patients of a private Hospital in North West India. National J of Community Medicine, 2013:4;485488.

3. Naqshbandi I, Quadri SYA, Yasmeen N, Bashir N. Seroprevalence and Risk Factors of Hepatitis B virus Infection among General Population of Srinagar Kashmir. Int.J of Contem Med Res 2016;3 (4):1050-1054.

4. Sood S, Malvankar S. Seroprevalence of Hepatitis B Surface Antigen,Antibodies to the Hepatitis C Virus,and Human Immunodeficiency Virus in a Hospital-Based Population in Jaipur,Rajasthan.Indian J Community Med.2010;35 (1):165-169.

5. Wu JF, Chang MH. Natural history of chronic hepatitis B virus infection from infancy to adult life-the mechanism of inflammation triggering and longterm impacts.J. BioMed Sci.2015;22:92: 1-7. 
6. Ananthanarayana R, Paniker CKJ, Text book of Microbiology, Universities Press(India) Private Limited 2003,9 th ed, pg:543-545.

7. Ocama P, Opio CK, Lee WM. HepatitisB virus infection: Current status. The American J Med. 2005;118,1413.e151413.e22.

8. Patel PA, Patel SP, Oza HV. Seroprevalence of Transfusion Transmitted Infections(TTIs) in Blood Donors at Western Ahmedabad-A secondary care Hospital Based Study.Int J Biol Med Res.2012;3(2): 1806-1810.

9. Supekar SN, Patel HL .Prevalence of Hepatitis B virus Infection in Young Students of Anand. Nat J Med Res 2012; 2(3):299-301.

10. Saraswathi KS, Aljabri F. The study of prevalence of Hepatitis B surface antigen during pregnancy in a tertiary care hospital,South India. Der Pharmacia Lettre, 2012,4(3):983-985.

11. Khaleel M, Syed A. Comparative study on Prevalence of Hepatitis B surface antigen among blood donors and in patient hospital attendees at a tertiary care hospital, Hyderabad. Ind J Bas Appl Med Resear 2016,5 (3):280-284.
12. Samatha P, Sireesha DM, Sowmya BS. Seroprevalence of Hepatitis B surface antigen, Antibodies to Hepatitis C\&HIV in a hospital based population.J Biosci Tech 2015,6 (1):597-601.

13. Singh J, Bhatia R, Khare S, Patnaik SK ,Biswas S, Lal $\mathrm{S}$ et al. Community studies on prevalence of $\mathrm{HBsAg}$ in two urban populations of southern India.Ind Paeiatr 2000,37 (2):149-52.

14. Bhawani Y, Rao PR, Sudhakar V. Seroprevalence of transfusion transmissible infections among blood donors in a tertiary care hospital of Andhra Pradesh. Biology and Medicine 2010,2 (4):45-48.

15. Chandra M, Khaja MN, Farees N, Poduri CD, Hussain MM, Habeeb M , Habibullah CM. Prevalence, risk factors and genotype distribution of $\mathrm{HCV}$ and $\mathrm{HBV}$ infection in the tribal population :a community based study in South India. Tropical Gastro 2003,24 (4):193-195.

16. Batham A, Gupta MA, Rastogi P, et al .Calculating Prevalence of Hepatitis B in India: Using Population Weights to look for Publication Bias in Conventional Meta-analysis. Ind J Paed $2009 ; 76: 1247-1257$.

*Corresponding author:

Dr Aruna Bula, Door No. 49-35-58/18; Flat-3D, Keerthana Enclave, Ngo's Colony, Visakhapatnam -530016, Andhra Pradesh, India

Phone: +91-891-9849025731

Email: aruna_8182@yahoo.com

Date of Submission : 17.10.2016

Financial or other Competing Interests: None. 